\title{
BÁO CÁO CA LÂM SÀNG: PHẪU THUẬT LỒNG NGỰC NỘI SOI CẮT NANG MÀNG NGOÀI TIM Ở VỊ TRÍ TRUNG THẤT GIŨ̉A
}

\author{
Nguyễn Minh Ngoc**, Đặng Quang Huy*
}

\section{TÓM TẮT}

Nang màng ngoài tim là tổn thương hiếm gặp, lành tính của màng ngoài tim. Chúng tôi trình bày một ca bệnh có nang màng ngoài tim kích thước lớn, nằm ở vị trí ít gặp là trung thất trước bên trái, đã được phẫu thuật bóc tách nang bằng phương pháp phẫu thuật lồng ngực nội soi (VATS) tại bệnh viện Tim Hà Nội.

\section{I. ĐẠTT VẤN ĐỀ}

Nang màng ngoài tim là tổn thương lành tính của màng ngoài tim. Nang màng ngoài tim chiếm $6 \%$ các khối u ở trung thất. Nang màng ngoài tim thường không gây triệu chứng lâm sàng, tuy nhiên những nang có kích thước lớn có thể chèn ép tổ chức xung quanh hoặc vỡ vào khoang màng tim, màng phổi gây ra những biến chứng nguy hiểm.Phương pháp điều trị triệt để nang màng ngoài tim là phẫu thuật. $[1,2]$

\section{CA LÂM SÀNG}

Bệnh nhân nam, 67 tuổi, tiền sử phát hiện nang màng ngoài tim cách vào viện 3 năm, kích thước $10 \times 10 \mathrm{~mm}$. Cách vào viện 2 tháng, bệnh nhân cảm thấy đau tức ngực tăng dần. Khám phát hiệnnang màng ngoài tim kích thước lớn. Bệnh nhân được nhập viện. Chụp cắt lớp vi tính (CLVT) lồng ngực có hình ảnh nang màng ngoài tim ở vị trí trung thất trước, lệch về bên trái, ranh giới rõ, kích thước $90 \times 37 \mathrm{~mm}$. Trong nang chứa đầy dịch tỉ trọng đồng nhất. Các thăm dò, xét nghiêm khác không có bất thường. Bệnh nhân đã được hội chẩn và đưa ra phương pháp xử trí phẫu thuật lồng ngực nội soi cắt nang màng ngoài tim.

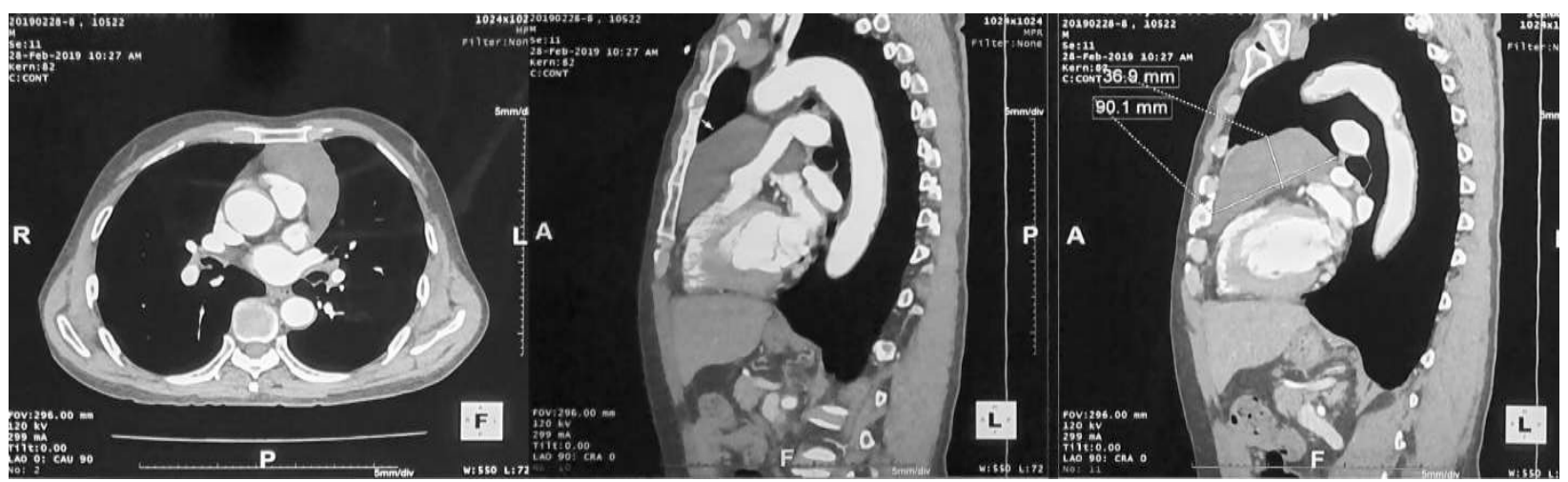

Hình 1: Vị trí nang màng tim trên phim chụp CLVT

Bệnh nhân được gây mê nội khí quản, sử dụng ống nội khí quản hai nòng, đặt tư thế nằm nghiêng trái $30^{\circ}$. Tiến hành đặt 03 lỗ trocar qua thành ngực, 01 lỗ trocar $12 \mathrm{~mm}$ ở vị trí khoang liên sườn IV đường nách trước cho dụng cụ tay trái, 011ỗ trocar $5 \mathrm{~mm}$ ở vị trí khoang liên sườn III đường nách giữa cho dụng cụ tay phải, và 01 lỗ trocar $5 \mathrm{~mm}$ ở vị trí khoang liên sườn IV đường nách giữa cho camera nội soi. Thông khí 1 bên phổi trong quá trình phẫu thuật. Thăm dò thấy nang màng ngoài tim kích thước lớn, khoảng
$15 \times 15 \times 6 \mathrm{~cm}$, vị trí ở trung thất trước, lệch về bên trái, giới hạn trên từ vùng đỉnh phổi trái, sau xương ức, đi xuống gần sát góc tim hoành trái. Nang đi ra trước gần sát với tuyến ức, và đi ra phía sau bám dưới thần kinh hoành trái. Nang có chèn ép vào thất trái, động mạch chủ và động mạch phổi trái.

\footnotetext{
* Bệnh viện Tim Hà Nội

Người chịu trách nhiệm khoa họ: ThS. Đặng Quang Huy

Ngày nhận bài: 01/05/2019 - Ngày Cho Phép Đăng: 15/05/2019 Phản Biện Khoa học: PGS.TS. Đặng Ngoc Hùng

GS.TS. Lê Ngoc Thành
} 


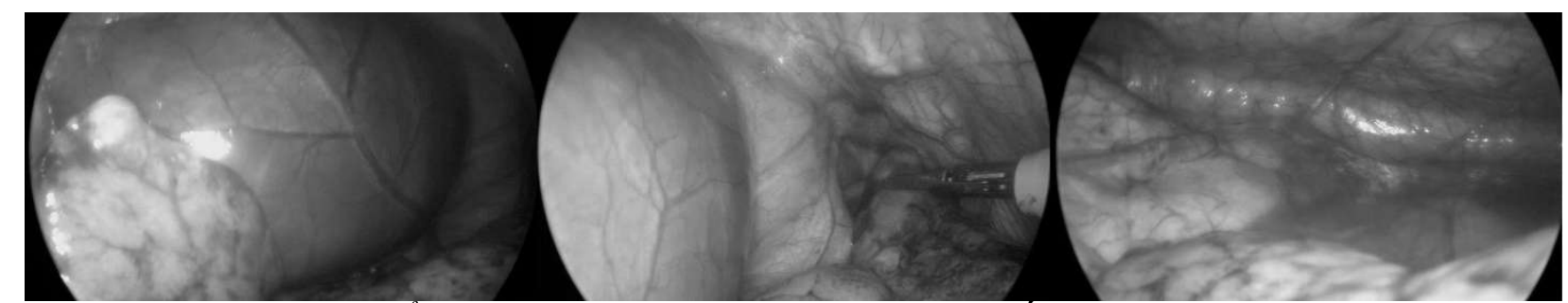

Hình 2: Hình dạng đại thể nang màng tim, giới hạn trên (sát tuyến ức) và giới hạn dưới (cách xa góc tim - hoành) của nang màng tim

Tiến hành mở nang, trong nang chứa đầy dịch màu nâu. Bóc tách toàn bộ nang khỏi các tổ chức xung quanh: màng ngoài tim, tuyến ức, thần kinh hoành trái. Gửi dịch và tổ chức nang làm giải phẫu bệnh. Cầm máu kỹ các diện bóc tách. Đặt 02 dẫn lưu màng phổi qua 2 lỗ trocar $5 \mathrm{~mm}, 1$ dẫn lưu đi xuống đáy phổi và 1 dẫn lưu lên đỉnh phổi. Đóng vết mổ.

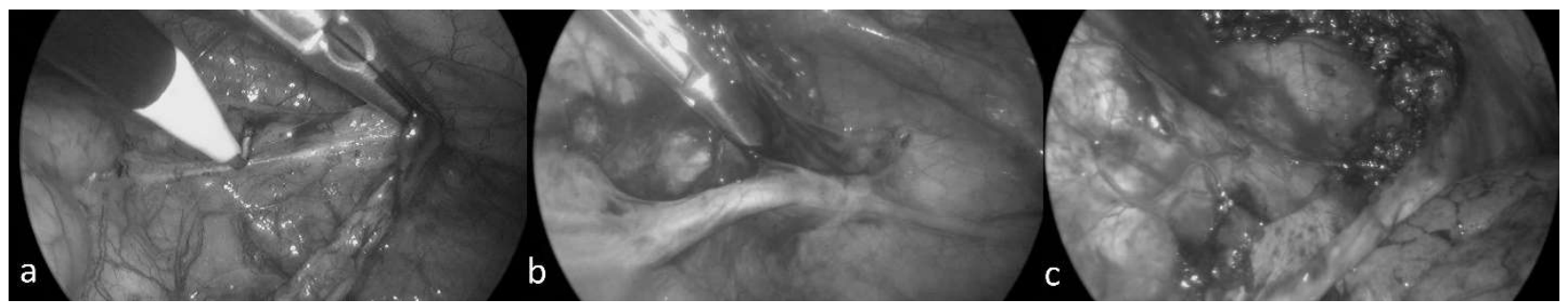

Hinh 3: (a) Bóc tách nang khỏi màng tim, (b) Bóc tách thần kinh hoành, (c) Hình ảnh sau khi bóc tách

Sau phẫu thuật, bệnh nhân được rút ống nội khí quản sau 3 giờ, rút dẫn lưu sau 48 giờ. Siêu âm tim sau mổ không còn hình ảnh nang màng tim. Không có liệt cơ hoànhsau mổ. Kết quả giải phẫu bệnh tổ chức nang là các tế bào trung mô lành tính, dịch nang chủ yếu tơ huyết và hồng cầu, không có các tế bào ác tính. Bệnh nhân được ra viện sau 05 ngày.

Kết quả khám lại sau 1 tháng: không thấy hình ảnh nang màng tim tái phát.

\section{BÀN LUẬN}

Nang màng ngoài tim là tổn thương lành tính, có tỉ lệ mắc là 1 trên 100.000 trường hợp, chiếm $6 \%$ các khối u ở trung thất $[1,2]$. Nguyên nhân chủ yếu là bẩm sinh, ngoài ra có thể do các nguyên nhân hiếm gặp như sau phẫu thuật tim, hoặc chấn thương. Nang màng ngoài tim thường không gây ra triệu chứng, và chỉ được phát hiện tình cờ khi khám sức khỏe. Khi người bệnh có các triệu chứng đau tức ngực, khó thở, ho nhiều là do nang phát triển kích thước lớn và chèn ép vào các tổ chức xung quanh[3,4]. Cũng có trường hợp nang vỡ vào màng phổi hoặc màng tim gây tràn dịch màng phổi hoặc tràn dịch màng tim, ép tim[5,6].Chẩn đoán nang màng ngoài tim dựa vào siêu âm tim, chụp cắt lớp vi tính lồng ngực, hoặc chụp cộng hưởng từ [2, 7]. Trong ca bệnh của chúng tôi, bệnh nhân đã được tình cờ phát hiện nang màng tim kích thước nhỏ khi khám sức khỏe, và được theo dõi trong 3 năm. Khi nang phát triển lớn, bệnh nhân có triệu chứng đau ngực.

Vị trí thường gặp của nang màng ngoài tim là ở góc tim - hoành, với tỉ lệ $70 \%$ ở bên phải và $28 \%$ ở bên trái. $2 \%$ còn lại là các vị trí khác[8]. Nang màng tim lớn gây triệu chứng thường đè ép vào tâm nhĩ phải, hoặc tâm thất, tâm nhĩ trái. Trong ca bệnh này, nang nằm ở vị trí ít gặp, trong trung thất trước, lệch sang trái, đè ép vào thất trái, 
động mạch chủ và động mạch phổi trái. Ranh giới liên quan tới tuyến ức và thần kinh hoành, do đó gây khó khăn cho quá trình bóc tách nang, với nguy cơ chảy máu và tổn thương thần kinh gây liệt cơ hoành.

Đối với các nang màng tim không có triệu chứng, thường người bệnh chỉ được theo dõi sự tiến triển của nang mà không điều trị gì. Khi nang màng tim gây triệu chứng, phẫu thuật bóc tách nang là phương pháp điều trị triệt để nhất[2]. Hiện nay phương pháp phẫu thuật lồng ngực nội soi (Video assisted thoracic surgery - VATS) đã chứng tỏ được hiệu quả trong điều trị các khối u trung thất và được áp dụng rộng rãi ở nhiều trung tâm trên thế giới và ở Việt Nam. Đối với trường hợp được báo cáo, phẫu thuật được tiến hành với 3 lỗ trocar trên thành ngực, không sử dụng dụng cụ banh xương sườn, do đó giảm đau, giảm nguy cơ chảy máu và giảm thời gian nằm viện cho bệnh nhân. Với sự hỗ trợ của camera nội soi, có thể quan sát rõ ràng và thực hiện bóc tách hiệu quả toàn bộ nang màng tim khỏi các tổ chức xung quanh. Trong trường hợp bệnh nhân của chúng tôi, nang màng timbám ở phỉa dưới thần kinh hoành trái, nang đã được bóc tách hoàn toàn mà không làm tổn thương thần kinh hoành, không có liệt cơ hoành sau mổ.

\section{KẾT LUẬN}

Nang màng ngoài tim là một tổn thương lành tính của màng tim, thường không gây triệu chứng. Khi nang màng ngoài tim phát triển lớn chèn ép các tổ chức xung quanh gây triệu chứng, phẫu thuật bóc tách nang màng tim là phương pháp điều trị triệt để. Phẫu thuật nội soi lồng ngực (VATS) là phương pháp hiệu quả, nhiều ưu điểm và được áp dụng rộng rãi trong điều trị nang màng tim nói riêng và các khối u trong trung thất nói chung.

\section{TÀI LIỆ THAM KHẢO}

1. Jarzabkowski, D.C. and D.B. Braunstein, Pericardial cyst: an incidental finding. J Am Osteopath Assoc, 1998. 98(8): p. 445-6.

2. Patel, J., et al., Pericardial cyst: case reports and a literature review. Echocardiography, 2004. 21(3): p. 269-72.

3. Ogah, O.S., et al., A large pericardial cyst presenting with severe chest pain: a case report and review of literature. Afr $\mathrm{J}$ Med Med Sci, 2009. 38(1): p. 83-6.

4. Stoller, J.K., C. Shaw, and R.A. Matthay, Enlarging, atypically located pericardial cyst. Recent experience and literature review. Chest, 1986. 89(3): p. 402-6.

5. Amr, B.S., T. Dalia, and A. Simmons, Acute cardiac tamponade secondary to ruptured pericardial cyst: Case report and literature review. J Cardiol Cases, 2018. 18(2): p. 43-46.

6. Ilhan, E., et al., An unusual presentation of pericardial cyst: recurrent syncope in a young patient. Cardiol J, 2012. 19(2): p. 188-91.

7. Padder, F.A., et al., Echocardiographic diagnosis of pericardial cyst. Am J Med Sci, 1997. 313(3): p. 191-2.

8. Hekmat, M., et al., Giant Pericardial Cyst: A Case Report and Review of Literature. Iran J Radiol, 2016. 13(1): p. e21921. 